\title{
Use of Quantitative and Qualitative Methods for Modelling Green Supply Chains
}

\author{
Blanka Tundys \\ Department of Logistics, Faculty of Management and Economics of Services, \\ University of Szczecin, Poland \\ E-mail: blanka.tundys@usz.edu.pl
}

\begin{abstract}
Interest in the field of the development and implementation of the principles of green supply chains is increasing. Among theorists and practitioners of management, they are seen as a new trend and an innovative strategy. Everincreasing customer requirements, the development of economies in the direction of closing the loop and the depletion of resources lead to a situation in which innovative solutions (including green supply chains) should be implemented. Qualitative and quantitative tools are used to assess their operations. This paper focuses largely on aspects of quantitative statistical methods that are used to assess individual elements of a supply chain, as well as a holistic approach to the evaluation of the entire chain. The methods that were chosen are an attempt to build a framework for a model and determine which of the tools are used in practice. The analysis includes an indication of the advantages, as well as the limitations, of the use of particular instruments. The second part of the paper includes an analysis of qualitative tools, devoting particular attention to tools and instruments from the area of management.
\end{abstract}

Keywords: green supply chain, qualitative and quantitative methods, management tools

\section{INTRODUCTION}

Study of the barriers and determinants of the functioning of green supply chains and their processes is a relatively new research field. Various methods, techniques, principles and concepts are used in the research process. A taxonomic approach, which organizes knowledge, as well as the presentation of the most common methods reported in the literature, is one of the main objectives of this work. It is important to present assessment models of green supply chains that include both quantitative and qualitative methods.

The integration of environmental factors into the framework of the supply chain is becoming increasingly important, in light of factors including managerial decisions. Regardless of the level (strategic, tactical or operational), the modeling methods and techniques presented support their application in supply chains. Quantitative and qualitative methods are used in practice and are implemented in order to assess the functioning of individual processes, cells and components, as well as the entire supply chain. The activities undertaken and the use of these types of tools have an impact both on the strategic management of the entire supply chain, and on those actions in the framework of operational management.
Considerations beyond the cognitive and ordered goals are also supported by the results of empirical studies relating to the use of qualitative methods (with particular emphasis on those in management) in the modeling and management of green supply chains in the Polish context.

The research methods used to evaluate green supply chains are qualitative and quantitative. By processes modeling, as well as to the assessment of individual processes and decisions in the chain are used a different approach and model types.

\section{AIM AND RESEARCH QUESTIONS}

This research has two principal objectives: (I) to identify the mathematical, statistical and operations research tools used to assess the activity, performance and level of the greening of the supply chain. This is possible on the basis of an analysis of the literature. The second goal (II) is to identify the management tools that can be used, as part of research on the greening of the supply chain. This process has been accompanied by practical verification, on the basis of empirical research conducted in business units in Poland. The goals are accompanied by specific objectives, which allowed for the achievement of the main objectives. These include: (1) classification of knowledge, including identification of the various methods and techniques for evaluating the functioning of green supply chains; (2) assignment of tools and techniques to specific processes and management levels; (3) an indication, based on empirical research, of which tools are used in Poland to evaluate supply-chain activities.

The stated purposes accompanied the following research thesis: (a) a large number of methods which are used to study the relationships in a supply chain are benefits / barriers to creating a supply-chain evaluation model; (b) standard methods of analysis of the supply chain could be dedicated to research on green supply chains; (c) a green supply chain requires dedicated and specific tools for the evaluation model; (d) analysis of selected industries showed that the knowledge and range of tools used by management to assess the functioning of a green supply chain are dependent on various considerations. In this regard, the sector, company size and role in the supply chain have great importance.

This approach allows us to indicate ways of modeling green supply chains and the variety of tools available for research on them, as well as showing the solutions that can be used to evaluate the usefulness of the available tools. Both 
elements may give rise to the creation of a conceptual model for assessing green supply chains, in which the elements typically associated with operations research are combined and reflect a holistic approach to evaluation of green supply chains.

\section{RESEARCH PROCESS}

The research process was divided into several stages, and describes two areas (empirical research and identification of qualitative and quantitative tools). In the first stage, a review of literature related to supply chains (with particular emphasis on green supply chains) was conducted. The review was performed in the context of identifying the quantitative tools in the area of operations research that are used to evaluate and measure processes in the chain. These analyses were based on literature studies. This phase also included analysis of the qualitative tools, with particular emphasis on management tools, in the context of their use for research related to green supply chains. A general assessment was made on the basis of the literature in order to show the extent to which various quantitative methods are most useful in the various processes. The next stage was the construction of a preliminary model - using tools for evaluating green supply chains (divided into levels of management: operational, tactical, strategic and process approaches). The next stage analyzed responses to a questionnaire on the use of tools to evaluate green supply chains. The questions were directed to three selected industries: Food Industry - Conventional, Food Industry Organic, Clothing manufacturing, Home appliance manufacturers, Grocery and general merchandise retail networks, Home appliance retail networks, Apparel retail networks. On the basis of a randomly selected sample, 332 companies were examined. The research process is shown in Figure 1.

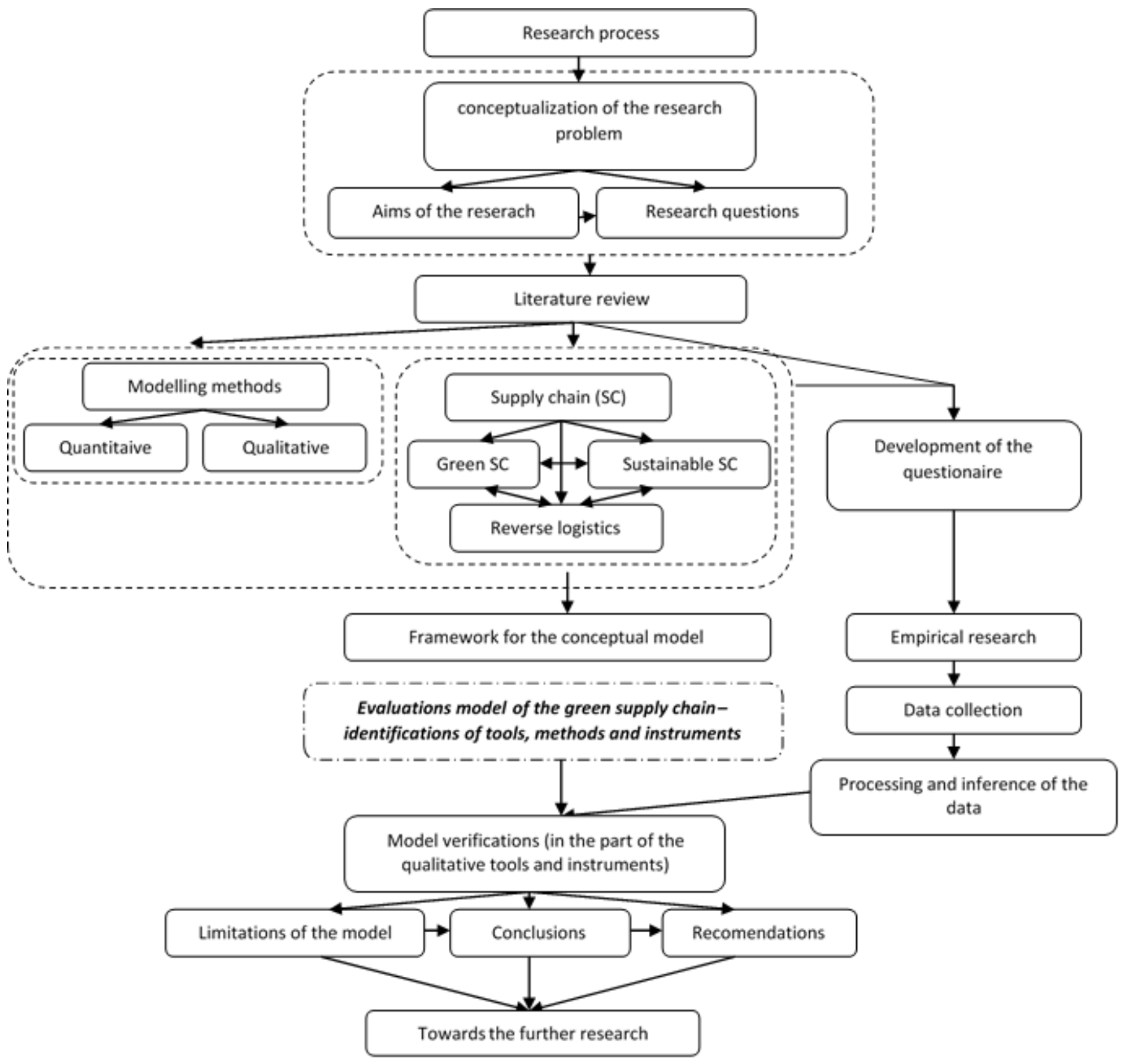

Figure 1 Research process 


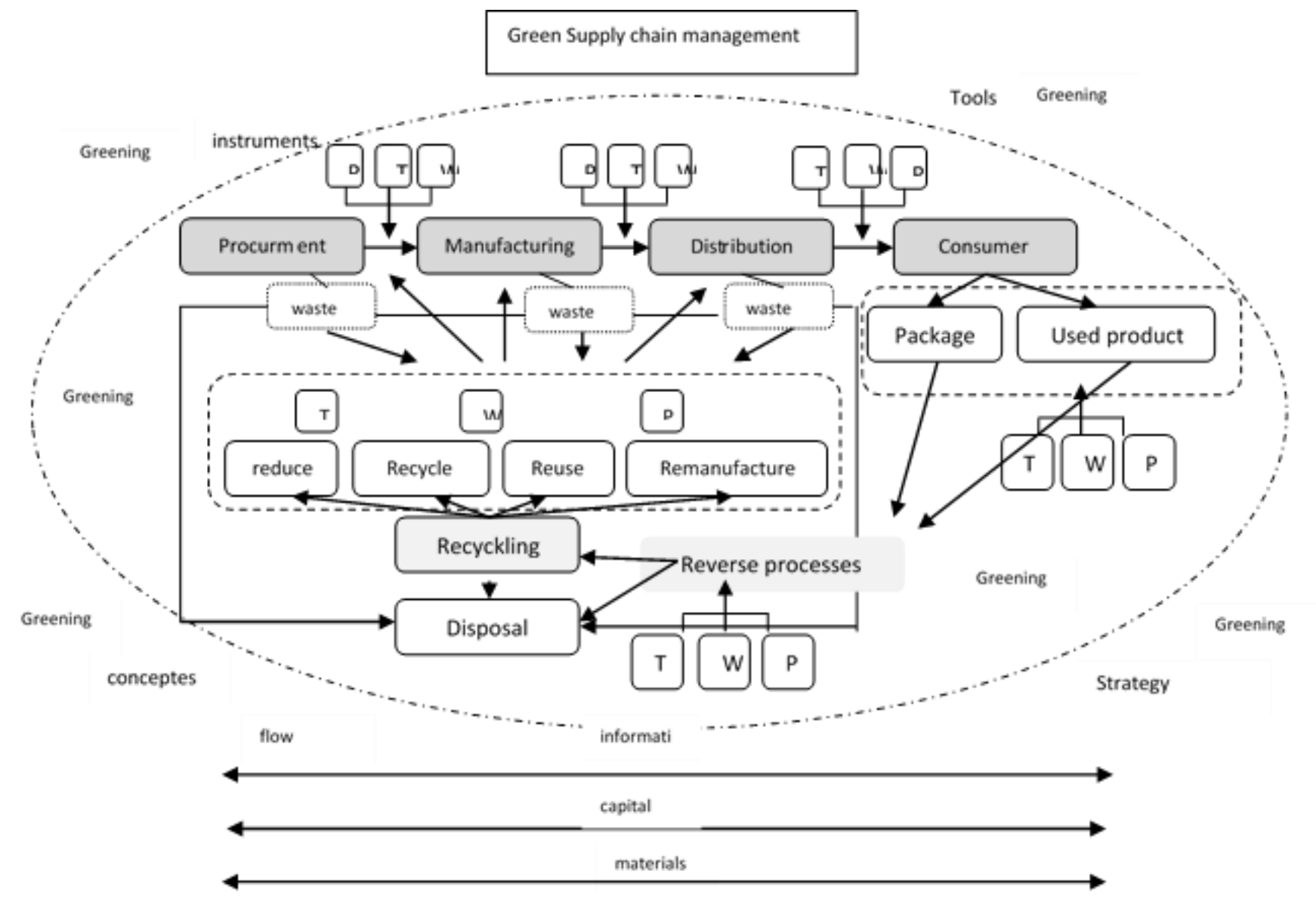

Figure 2 Green holistic approach in the supply chain

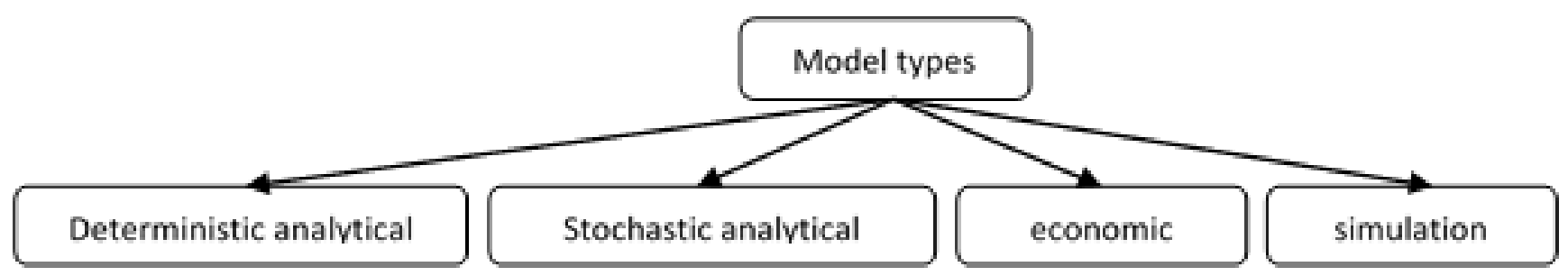

Figure 3 Model types

Source: On the basis on: Beamon, B. M. (1998)

Conclusions were drawn on this basis, and limitations were identified both in the study and in the use of particular tools. On the basis of the literature, the quantitative methods most often used in practice were identified. On the basis of empirical research conducted by the author, the tools and concepts related to management and their usefulness in Polish conditions were identified. The part of the model relating to the use of management methods was identified. The second area of the model and its verification is a further part of the research on green supply chains in Poland.

It should be noted that the literature is one of the most important bases for further empirical research. The literature allows us to find the ideas, concepts and methods used in the research field without having to rely on data collected in person by the author. It allows the review, identification, critical evaluation and resumption of studies already carried out, giving pointers to identify problems and adapt them to the needs of detailed research. Additionally, it helps to identify the conceptual content of the field (Fink, 1998) and develop the theory.

An overview of the literature allows the identification of the basic concepts, but also of the items whose identification is the most important goal of this article: the tools (qualitative and quantitative) that can be used to build a model for assessing a green supply chain. Here it was important to verify a model based on empirical research. This research is conceptual, and part of the conceptual model has been empirically verified. The structure of the model should take into account a different paradigm in connection with the use of mixed research methods. It should be a quantitative paradigm based on all stages of the research process for the quantification of the observed reality. In the qualitative paradigm, quantitative elements are largely ignored, and the effect of such research is the interpretation of the test subject and the verbalization of real-world experience (Bortz, Döring 2002). 


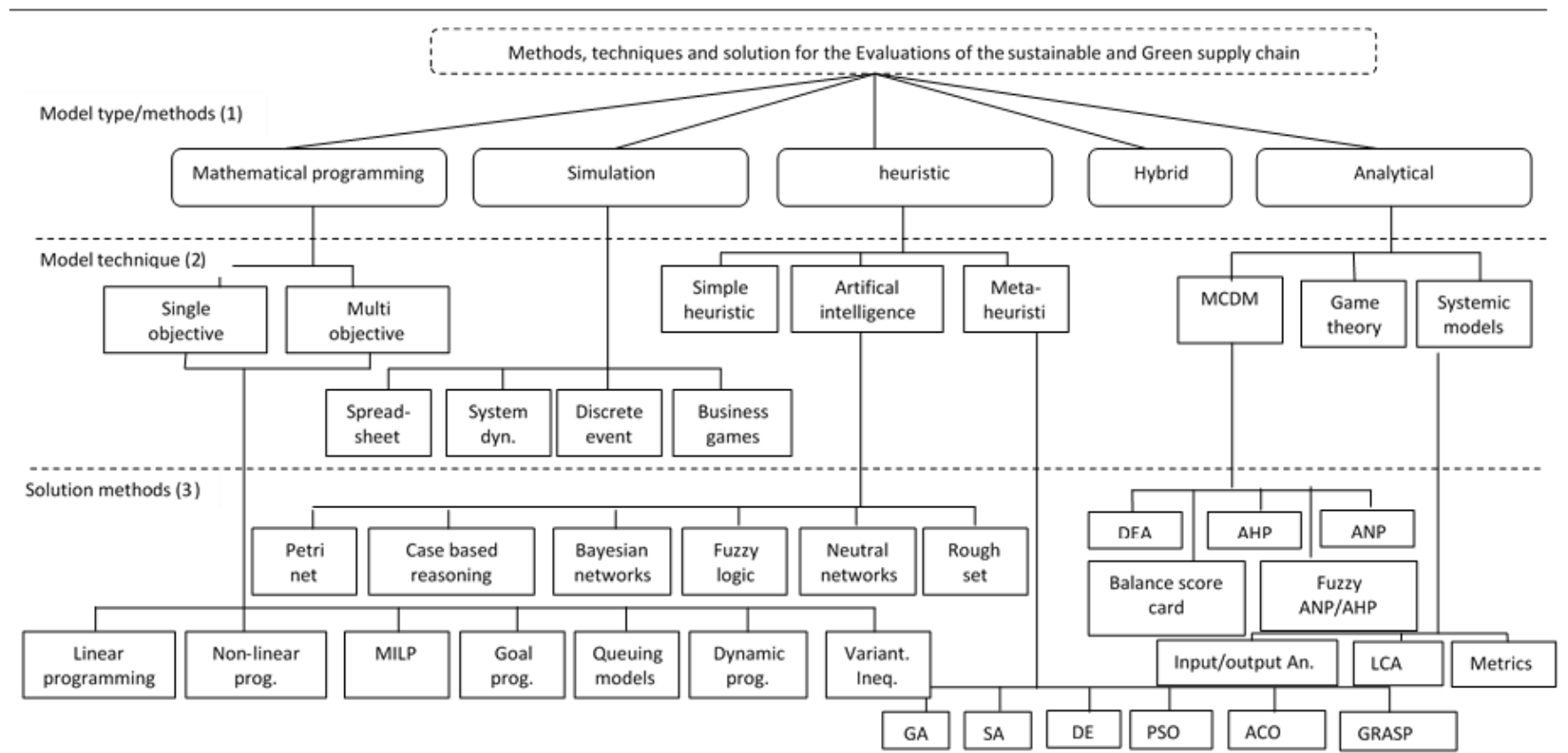

Figure 4 Methods, techniques and quantitative tools used to assessment of the sustainability and green supply chain

Source: based on: Sasikumar \& Kannan (2009) and Brandenburg et al. (2014).

\section{LITERATURE REVIEW}

\section{a. Green Supply Chain}

The literature in this area is extremely rich. It should be noted that the greatest contribution to the literature came from: Zhu, Q., Sarkis, J. (2004, 2006), Beamon (2008) and S. K. Srivastava, (2007) Vachon \& Klassen (2006), Carter \& Jennings (2004), Salam, (2009), Lee, (2008); Walker et al., (2008), Sarkis et al. (2011), Capgemini Consulting (2011), Carter \& Dresner (2001), Lamming \& Hampson (1996), Welford \& Frost (2006), Rao \& Holt (2005), Carter \& Carter (1998); Hall, (2000), Preuss, (2001). Kleindorfer et al. (2005); Rothenberg et al. (2001); Simpson \& Power (2007), Guide \& Van Wassenhove (2009); Wu \& Dunn (1995), Seuring (2012), Brandenburg et al. (2014), Seuring, \& Müller (2008) Yakovleva et al. (2012).

This subject has been identified as a research field for more than 20 years. However, at this point it should be noted that there are visible deficiencies both in the literature and in the practice of business in Poland. Therefore, the construction of the model and its verification in management methods and qualitative factors was based on empirical research conducted in Polish enterprises.

In the context of this discussion, it is important to indicate that this is a holistic approach, as well as a redesigned way of thinking and using the current method to analyze supply chain management, which takes into account environmental aspects.

In particular, it seeks to identify the organization of logistical processes that is the least burdensome and harmful to the environment. The resources of the literature offer the ability to appreciate that the essence of a green supply chain (in the context of projects, practical solutions, new management systems) is integration of processes, operations and environmental activities, while simultaneously increasing the standards of logistics and implementation of modern concepts - redesigning the supply chain. Improving green supply chain practices covers the area of product lifecycle management, the implementation of specific tools and components in the processes taking place in the chain: procurement, production, distribution, recycling, packaging, transportation and storage; paying attention to aspects of time, quality, cost and flexibility. In addition to the definition of a green supply chain and the processes included in its scope, the concept of holistic management of a green supply chain must be defined. "Green SCM is defined as an integrating environmental thinking into supply-chain management, including product design, material sourcing and selection, manufacturing processes, delivery of the final product to the consumers as well as end-of-life management of the product after its useful life" (Srivastava, 2007)

Guided by a holistic approach, it should be indicated that the greening of processes must occur at every stage of the life cycle of the product and the processes related to reverse logistics (including recycling). Thus, specific methods and tools can be used to assess the functioning of the supply chain. The holistic approach is presented in Figure 2.

An approach that takes into account the greening of processes, which is to form the basis and framework for a green supply chain, must address all processes; it must include a redesign of strategy and alignment of the appropriate tools and instruments. "Greening" refers to processes as well the choice of the strategy and tools to support them. Green supply chains differ from traditional ones in that green supply chain management is integrated into the entire process, including planning, procurement, production, consumption and reverse logistics. The entire supply chain is managed as a green system, and every process focuses on environmental management and risk control. (Sulistio, \& Rini, 2015). 
Table 1 Methods and techniques using in the evaluations of the supply chain

\begin{tabular}{|c|c|c|c|c|}
\hline \multicolumn{5}{|c|}{ Criteria } \\
\hline Management approach & $\begin{array}{c}\text { External and social } \\
\text { aspect }\end{array}$ & $\begin{array}{l}\text { Organizational } \\
\text { change }\end{array}$ & Technical aspects & $\begin{array}{l}\text { Performance } \\
\text { measuerment }\end{array}$ \\
\hline \multicolumn{5}{|c|}{ Sub-criteria } \\
\hline $\begin{array}{l}\text { - Top management } \\
\text { commitment and support } \\
\text { - Environmental policy } \\
\text { - International, governmental } \\
\text { and domestic environmental } \\
\text { agreements and legislations }\end{array}$ & $\begin{array}{l}\text { - Effective } \\
\text { communication within } \\
\text { companies and } \\
\text { suppliers } \\
\text { - Environmental } \\
\text { auditing for suppliers } \\
\text { - Green image }\end{array}$ & $\begin{array}{l}\text { - Environmental } \\
\text { education and } \\
\text { training } \\
\text { - Manpower } \\
\text { involvement }\end{array}$ & $\begin{array}{l}\text { - Green purchasing } \\
\text { - Green design } \\
\text { - Green and cleaner } \\
\text { production } \\
\text { - Green packaging } \\
\text { - Green labels } \\
\text { - Reuse, recycle and } \\
\text { recovery of material } \\
\text { - Reduce energy } \\
\text { consumption }\end{array}$ & $\begin{array}{l}\text { - Cost } \\
\text { - Flexibility } \\
\text { - Time } \\
\text { - Consumer } \\
\text { Responsibility } \\
\text { - Quality }\end{array}$ \\
\hline \multicolumn{5}{|c|}{ Methods and techniques } \\
\hline \multicolumn{5}{|c|}{ 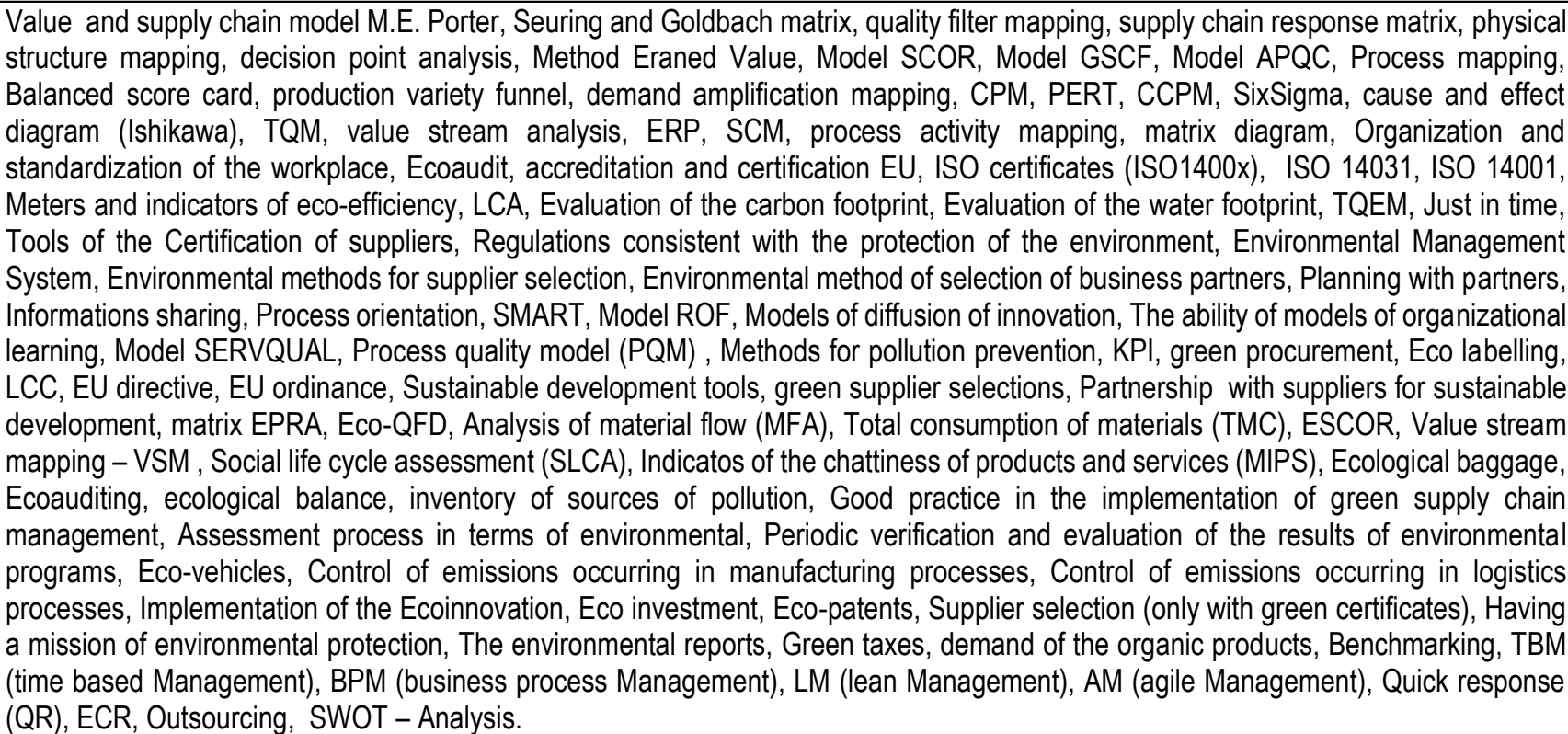 } \\
\hline
\end{tabular}

Source: Witkowski (2012), Ciesielski (2009)

\section{b. Test Methods Used to Evaluate Green Supply Chains}

Research methods can be divided into several types, primarily quantitative and qualitative methods. Quantitative research is based on measurement of quantity or amount and is applicable to phenomena that can be expressed in terms of quantity. Qualitative research, on the other hand, is concerned with qualitative phenomenon, i.e., phenomena relating to or involving quality or kind (Kothari, 2004).

A supply chain can be assessed from various points of view, and taking into account various approaches, and thus different methods and techniques. For this research it is important to identify the qualitative and quantitative tools useful for assessing a green supply chain. Research using various kinds of models can be utilized (Figure 3).

Quantitative methods are usually based on operations research, mathematical models and econometrics. Meanwhile, qualitative methods are based on "soft" concepts and techniques, including test methods, techniques and management tools to assess the functioning of a green supply chain.

Based on the literature, it should be noted that quantitative methods are a large group, and are used to evaluate the activities of the supply chain in the context of the greening of processes. Based on: Brandenburg, et al. (2014), Sasikumar \& Kannan (2009), a wide range of methods, techniques and quantitative tools used to assess sustainability and green supply chains may be present (Figure 4).

Also on the basis of the literature, concepts and tools related to more qualitative research may be identified, including management concepts that evaluate the functioning of a green supply chain. Selected methods are presented in Table 1. Certainly, an important element will be the introduction into the chain of an environmental management system. These tools and methods are chosen based on a quantitative survey (by percentage) and included the use of new strategies, concepts and tools for the development and evaluation of supply chains.

Criteria and sub-criteria as a basis to build models for green supply chain evaluation can also be identified (Table 1). For these criteria, it is possible to adjust the appropriate methods and verifiable techniques, and on this basis to build models for qualitative research, including management concepts, which evaluate the functioning of a green supply chain. 


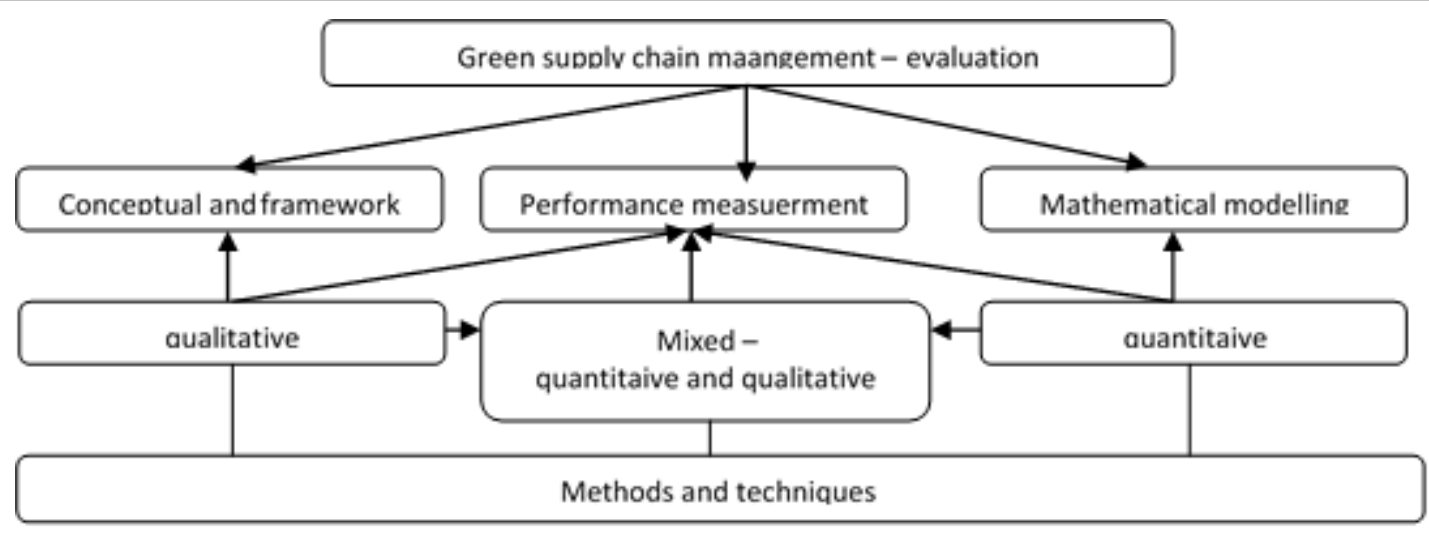

Figure 5 Evaluation model - framework

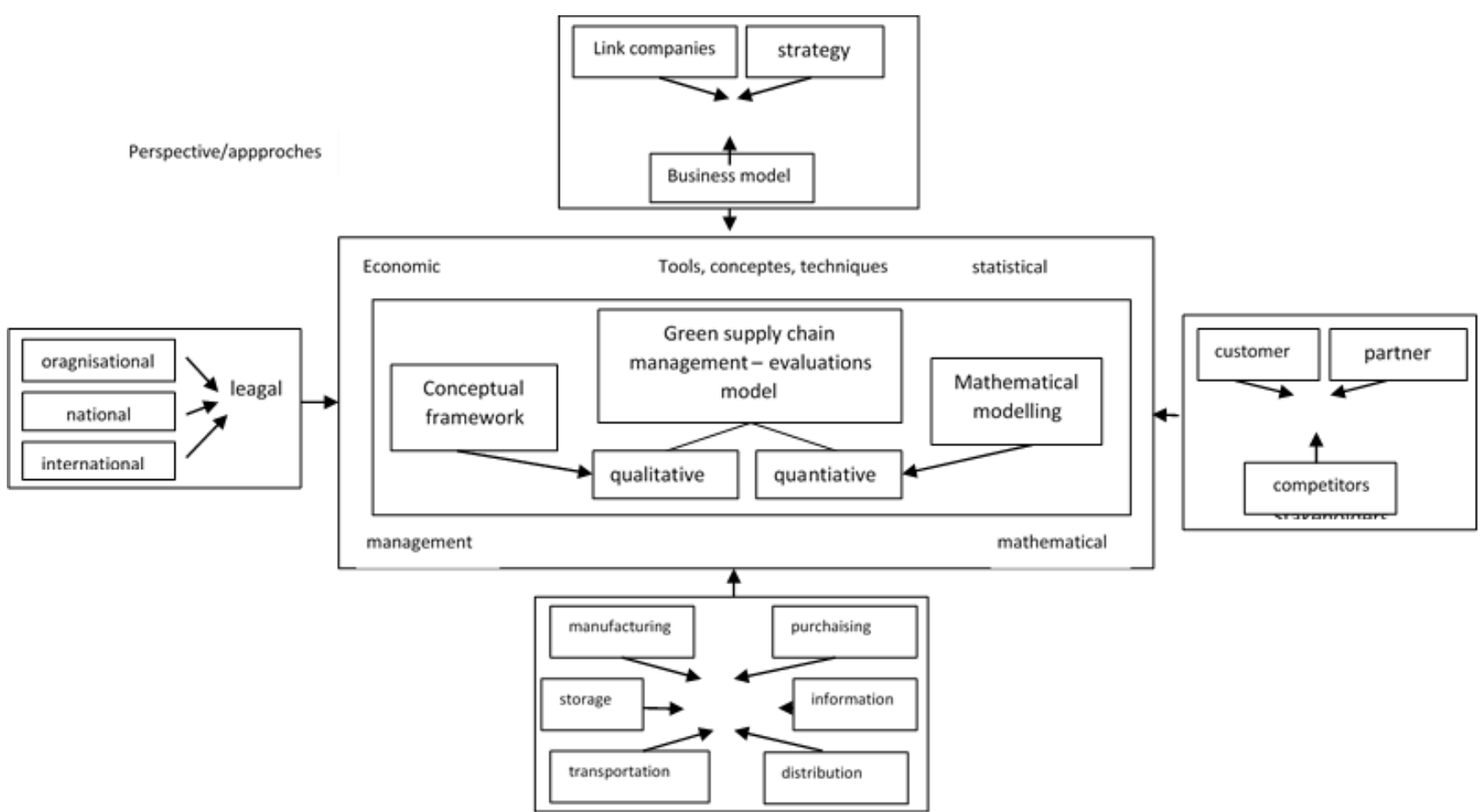

Figure 6 Evaluation model of the green supply chain

\section{EVALUATION OF GREEN SUPPLY CHAINS - MODELLING AND PRACTICAL VERIFICATIONS}

An evaluation model (Figure 5) can be created taking into account various processes. The most common methods in the literature are classified as: (1) Framework and concepts; (2) performance measurement; (3) mathematical modeling. The various techniques and parameters may be used in methods of quantitative and qualitative assessment as the basis for testing the functioning of a green supply chain.

A framework model has been developed (Figure 6), showing areas and perspectives that are taken into account to create an evaluation model using quantitative and qualitative tools.
On the basis of empirical research, it can indicate which of the methods and techniques were used to evaluate and parameterize a green supply chain. Another important element is indicating relationships, and whether there are correlations between certain factors and the methods used.

A survey using a questionnaire was conducted throughout Poland, using the CATI method. The survey was directed to these sectors: Food Industry - Conventional, Food Industry - Organic, Apparel manufacturing, Home appliance manufacturers, Grocery and general merchandise retail networks, Home appliance sales networks, Clothing retail networks. The parameters of the study were: number of employees > 99 people; responders were middle to senior levels of management: supply chain manager, logistics manager, head of logistics or supply chain, procurement and purchasing manager. The sample was designed to have statistical significance. The respondents were asked to answer using a five-point Likert-type scale (1- never/very rarely, 5 - very often/always). Some respondents did not 
reply to the questions, but this did not invalidate the outcome. The number of companies selected was 332. The respondents had a choice of 96 criteria, including general tools, tools used to evaluate the supply chain and tools dedicated to green supply chains. The spectrum was broad and included: tools, management concepts and instruments, legal aspects and organizational and financial activities (Tables 2 and 3). The results do not always add up to $100 \%$, because the total includes respondents who did not reply to all questions.

The results of the study are quite surprising, especially if we consider the sectoral approach. The tables clearly show that tools related to dedicated solutions for green supply chains are often used. Presented tools and concepts are also dedicated to each chain. This wide range indicates that not all tools are known, which is one reason why they are not used. The most important fact is that virtually all sectors indicated the use of performance assessment and the functioning of the chain SCOR model, but Green SCOR is not popular. This may result either from its area of operation, or from knowledge of the procedures and the popularity of this tool. Regardless of the industry, the largest percentage of "yes" and "always yes" responses appeared for the following tools: quality filter mapping, supply chain response matrix, GSCF model, PERT, balanced scorecard, production variety funnel, cause and effect diagram (Ishikawa), Organization and standardization of the workplace, Ecoaudit, EU accreditation and certification, ISO 14031, ISO 14001, Evaluation of the carbon footprint, Evaluation of the water footprint, ROF model, EU directives and EU ordinances, green supplier selections, Partnership with suppliers for sustainable development, Material flow analysis (MFA), Ecological baggage, ecological balance, supplier selection (only with green certificates), benchmarking and outsourcing, KPI.

An interesting observation is the lack of interest in LCA and in concurrent study of carbon and water footprints (more by networks than by the producers themselves, but this is already apparent from the very specific nature of the structure of the supply chain). A lot of interest in LCC is associated with costs throughout the life cycle. Then dedicate a well-known tool which is QFD to assess from the point of view of Eco also is not popular. When interpreting the results, it should be pointed out that among the surveyed companies representing manufacturing, in each of the groups the following were used to evaluate the supply chain (including evaluation of its greening): M.E. Porter value and supply chain model, quality filter mapping, supply chain response matrix, GSCF model, balanced scorecard, production variety funnel, PERT, cause and effect diagram (Ishikawa), value stream analysis, SCM, matrix diagram, Organization and standardization of the workplace, Ecoaudit, EU accreditation and certification, ISO 14031, ISO 14001, Evaluation of the carbon footprint, Evaluation of the water footprint, Supplier certification tools, Environmental method of selection of business partners, ROF model, organizational learning models, LCC, EU ordinances, green supplier selections, Partnership with suppliers for sustainable development, Social life cycle assessment (SLCA), Benchmarking, Outsourcing.

These elements can be used as an indication for the construction of an assessment model, and the elements which are already used can be the basis for an expansion of the evaluation model of a green supply chain. As we can see, not all elements are dedicated to the assessment of greening in the chain; general tools are also used. The location and role in the chain (manufacturer, seller) also have an influence on the specific nature of the tools used.

Referring to the sales network, and thus another link in the supply chain, it can be demonstrated that similar methods are used as at the manufacturing stage. The differences are in the percentage range, and in actions that are typically used in production processes. The most common methods include: quality filter mapping, supply chain response matrix, GSCF model, Process mapping, balanced scorecard, production variety funnel, PERT, cause and effect diagram (Ishikawa), value stream analysis, ERP, SCM, Organization and standardization of the workplace, Ecoaudit, EU accreditation and certification, ISO 14031, ISO 14001, Evaluation of the carbon footprint, Evaluation of the water footprint, Information sharing, ROF model, LCC, EU directives, green supplier selections, Partnership with suppliers for sustainable development, material flow analysis (MFA), Ecological baggage, Ecoaudit, ecological balance, Periodic verification and evaluation of the results of environmental programs, Eco-vehicles, Control of emissions occurring in manufacturing processes, Control of emissions occurring in logistics processes, Eco-patents, Supplier selection (only with green certificates), Green taxes, Benchmarking, Outsourcing. Increasingly important here are: green taxes, possession of eco-patents, the use of clean vehicles, calculation and awareness of environmental baggage and ecological balances, as well as exchanging and sharing information, and partnership for joint environmental action.

The most frequently occurring elements, taking into account all the surveyed companies and generalizing the considerations, are presented in Table 4. They can provide a framework directory for the basic assessment model of a green supply chain, including methods, tools and instruments for the assessment of supply chain management and legal and administrative regulation. 
Table 2 Analysis of the methods, tools and concepts - empirical verifications - general and manufacturing

\begin{tabular}{|c|c|c|c|c|c|c|c|c|c|c|c|c|c|c|c|}
\hline \multirow{3}{*}{ Methods, instruments and concepts } & & & & \multicolumn{12}{|c|}{ Manufacturing } \\
\hline & \multicolumn{3}{|c|}{ general } & \multicolumn{3}{|c|}{$\begin{array}{l}\text { Food Industry - } \\
\text { Conventional }\end{array}$} & \multicolumn{3}{|c|}{ Food Industry - organic } & \multicolumn{3}{|c|}{$\begin{array}{l}\text { Wearing apparel } \\
\text { manufacturing }\end{array}$} & \multicolumn{3}{|c|}{$\begin{array}{l}\text { Home appliance } \\
\text { manufacturers }\end{array}$} \\
\hline & $\begin{array}{l}\text { Nol } \\
\text { not } \\
\text { use }\end{array}$ & $\begin{array}{c}\text { no } \\
\text { opinion }\end{array}$ & $\begin{array}{c}\text { Yes/ } \\
\text { always } \\
\text { use }\end{array}$ & $\begin{array}{l}\text { Nol } \\
\text { not } \\
\text { use }\end{array}$ & $\begin{array}{l}\text { no } \\
\text { opinion }\end{array}$ & $\begin{array}{c}\text { Yes/ } \\
\text { always } \\
\text { use }\end{array}$ & $\begin{array}{l}\text { Nol } \\
\text { not } \\
\text { use }\end{array}$ & $\begin{array}{c}\text { no } \\
\text { opinion }\end{array}$ & $\begin{array}{c}\text { Yes/ } \\
\text { always } \\
\text { use }\end{array}$ & $\begin{array}{l}\text { Nol } \\
\text { not } \\
\text { use }\end{array}$ & $\begin{array}{c}\text { no } \\
\text { opinion }\end{array}$ & $\begin{array}{c}\text { Yes/ } \\
\text { always } \\
\text { use }\end{array}$ & $\begin{array}{l}\text { Nol } \\
\text { not } \\
\text { use }\end{array}$ & $\begin{array}{c}\text { no } \\
\text { opinion }\end{array}$ & $\begin{array}{c}\text { Yes/ } \\
\text { always } \\
\text { use }\end{array}$ \\
\hline Value and supply chain model M.E. Porter & 30,49 & 14,80 & 43,48 & 34,35 & 16,67 & 48,98 & 30,49 & 14,80 & 43,48 & 32,43 & 14,85 & 43,24 & 33,33 & 16,67 & 33,33 \\
\hline Seuring and Goldbach matrix & 21,03 & 53,45 & 11,15 & 24,56 & 62,42 & 13,02 & 21,03 & 53,45 & 11,15 & 20,00 & 52,94 & 10,00 & 0,00 & 100,00 & 0,00 \\
\hline quality filter mapping & 22,27 & 6,05 & 52,07 & 27,71 & 7,52 & 64,77 & 22,27 & 6,05 & 52,07 & 19,23 & 5,96 & 53,85 & 25,00 & 0,00 & 50,00 \\
\hline supply chain response matrix & 25,71 & 13,69 & 32,58 & 35,72 & 19,01 & 45,27 & 25,71 & 13,69 & 32,58 & 25,71 & 13,30 & 31,43 & 20,00 & 20,00 & 40,00 \\
\hline physical structure mapping & 38,17 & 8,54 & 40,19 & 43,93 & 9,82 & 46,25 & 38,17 & 8,54 & 40,19 & 37,84 & 8,45 & 40,54 & 40,00 & 0,00 & 40,00 \\
\hline decision point analysis & 57,19 & 0,24 & 33,79 & 62,70 & 0,26 & 37,04 & 57,19 & 0,24 & 33,79 & 55,88 & 0,24 & 35,29 & 50,00 & 0,00 & 50,00 \\
\hline Method Eraned Value & 42,87 & 24,85 & 29,38 & 44,15 & 25,59 & 30,26 & 42,87 & 24,85 & 29,38 & 42,50 & 24,40 & 30,00 & 40,00 & 20,00 & 40,00 \\
\hline Model SCOR & 37,70 & 22,74 & 12,13 & 51,95 & 31,34 & 16,71 & 37,70 & 22,74 & 12,13 & 36,84 & 23,66 & 15,79 & 33,33 & 33,33 & 0,00 \\
\hline Model GSCF & 2,99 & 0,37 & 76,80 & 3,73 & 0,46 & 95,81 & 2,99 & 0,37 & 76,80 & 0,00 & 0,37 & 78,26 & 0,00 & 0,00 & 75,00 \\
\hline Model APQC & 34,27 & 17,05 & 26,32 & 44,14 & 21,96 & 33,90 & 34,27 & 17,05 & 26,32 & 33,33 & 17,17 & 26,67 & 33,33 & 16,67 & 33,33 \\
\hline Process mapping & 10,45 & 20,56 & 44,89 & 13,77 & 27,09 & 59,14 & 10,45 & 20,56 & 44,89 & 10,87 & 20,41 & 45,65 & 16,67 & 16,67 & 33,33 \\
\hline Balanced score card & 34,73 & 5,02 & 58,72 & 35,27 & 5,10 & 59,63 & 34,73 & 5,02 & 58,72 & 35,00 & 5,12 & 60,00 & 50,00 & 0,00 & 50,00 \\
\hline production variety funnel & 6,93 & 14,50 & 47,04 & 10,12 & 21,17 & 68,71 & 6,93 & 14,50 & 47,04 & 9,09 & 14,55 & 45,45 & 0,00 & 0,00 & 50,00 \\
\hline demand amplification mapping & 31,96 & 25,89 & 29,63 & 36,53 & 29,59 & 33,87 & 31,96 & 25,89 & 29,63 & 30,77 & 26,48 & 30,77 & 20,00 & 20,00 & 40,00 \\
\hline CPM & 44,96 & 4,35 & 38,95 & 50,94 & 4,92 & 44,13 & 44,96 & 4,35 & 38,95 & 44,44 & 4,43 & 40,74 & 50,00 & 0,00 & 50,00 \\
\hline PERT & 28,27 & 21,16 & 42,51 & 30,75 & 23,02 & 46,24 & 28,27 & 21,16 & 42,51 & 27,08 & 20,91 & 43,75 & 33,33 & 16,67 & 33,33 \\
\hline CCPM & 32,59 & 31,06 & 17,00 & 40,41 & 38,51 & 21,08 & 32,59 & 31,06 & 17,00 & 33,33 & 31,30 & 18,18 & 25,00 & 25,00 & 25,00 \\
\hline SixSigma & 36,42 & 13,08 & 33,60 & 43,98 & 15,74 & 40,28 & 36,19 & 13,33 & 33,33 & 36,67 & 13,33 & 33,33 & 36,36 & 18,18 & 27,27 \\
\hline cause and effect diagram (Ishikawa) & 21,69 & 15,66 & 36,45 & 29,92 & 21,26 & 48,82 & 21,43 & 15,71 & 37,14 & 22,03 & 15,25 & 35,59 & 14,29 & 14,29 & 42,86 \\
\hline TQM & 30,17 & 19,57 & 32,45 & 36,71 & 23,81 & 39,48 & 30,17 & 19,57 & 32,45 & 30,00 & 20,34 & 32,00 & 33,33 & 16,67 & 33,33 \\
\hline value stream analysis & 27,58 & 22,05 & 46,53 & 28,68 & 22,93 & 48,39 & 27,58 & 22,05 & 46,53 & 26,32 & 22,79 & 47,37 & 25,00 & 25,00 & 50,00 \\
\hline ERP & 12,40 & 35,72 & 34,76 & 14,96 & 43,10 & 41,94 & 12,40 & 35,72 & 34,76 & 12,50 & 35,85 & 33,33 & 0,00 & 33,33 & 33,33 \\
\hline SCM & 26,46 & 10,85 & 37,10 & 35,56 & 14,58 & 49,87 & 26,46 & 10,85 & 37,10 & 27,59 & 10,47 & 37,93 & 50,00 & 0,00 & 25,00 \\
\hline process activity mapping & 41,20 & 25,72 & 26,90 & 43,91 & 27,41 & 28,67 & 41,20 & 25,72 & 26,90 & 41,67 & 26,95 & 25,00 & 66,67 & 33,33 & 0,00 \\
\hline matrix diagram & 21,71 & 23,49 & 31,73 & 28,22 & 30,53 & 41,25 & 21,71 & 23,49 & 31,73 & 21,74 & 23,46 & 30,43 & 20,00 & 20,00 & 40,00 \\
\hline $\begin{array}{l}\text { Organization and standardization of the } \\
\text { workplace }\end{array}$ & 8,18 & 26,52 & 48,84 & 9,79 & 31,75 & 58,46 & 8,18 & 26,52 & 48,84 & 8,82 & 26,32 & 47,06 & 0,00 & 25,00 & 50,00 \\
\hline
\end{tabular}


Table 2 Analysis of the methods, tools and concepts - empirical verifications - general and manufacturing (Con't)

\begin{tabular}{|c|c|c|c|c|c|c|c|c|c|c|c|c|c|c|c|}
\hline Ecoaudit & 22,47 & 14,47 & 47,51 & 26,60 & 17,14 & 56,26 & 22,47 & 14,47 & 47,51 & 23,53 & 14,00 & 47,06 & 20,00 & 20,00 & 40,00 \\
\hline accreditation and certification EU & 7,75 & 34,84 & 36,19 & 9,84 & 44,22 & 45,94 & 7,75 & 34,84 & 36,19 & 5,26 & 36,42 & 36,84 & 0,00 & 33,33 & 33,33 \\
\hline ISO certificates (ISO1400x) & 34,56 & 14,23 & 28,86 & 44,50 & 18,33 & 37,17 & 34,56 & 14,23 & 28,86 & 35,42 & 13,93 & 29,17 & 33,33 & 16,67 & 33,33 \\
\hline ISO 14031 & 7,96 & 0,42 & 48,23 & 14,06 & 0,74 & 85,21 & 7,96 & 0,42 & 48,23 & 8,00 & 0,41 & 48,00 & 0,00 & 0,00 & 50,00 \\
\hline ISO 14001 & 11,69 & 16,41 & 38,07 & 17,66 & 24,80 & 57,54 & 11,69 & 16,41 & 38,07 & 10,00 & 16,46 & 40,00 & 0,00 & 25,00 & 50,00 \\
\hline Meters and indicators of eco-efficiency & 34,22 & 20,10 & 25,11 & 43,08 & 25,31 & 31,61 & 34,22 & 20,10 & 25,11 & 33,33 & 20,03 & 26,19 & 25,00 & 12,50 & 50,00 \\
\hline LCA & 41,90 & 10,80 & 37,53 & 38,32 & 21,60 & 40,08 & 41,46 & 10,98 & 37,80 & 42,03 & 10,14 & 37,68 & 40,00 & 10,00 & 40,00 \\
\hline Evaluation of the carbon footprint & 14,10 & 22,08 & 44,30 & 17,53 & 27,43 & 55,04 & 14,10 & 22,08 & 44,30 & 13,89 & 21,81 & 44,44 & 20,00 & 20,00 & 40,00 \\
\hline Evaluation of the water footprint & 21,75 & 23,24 & 40,32 & 25,50 & 27,24 & 47,26 & 21,75 & 23,24 & 40,32 & 21,62 & 23,11 & 40,54 & 20,00 & 20,00 & 40,00 \\
\hline TQEM & 41,92 & 5,26 & 14,06 & 68,45 & 8,59 & 22,96 & 41,92 & 5,26 & 14,06 & 44,00 & 5,36 & 12,00 & 50,00 & 0,00 & 0,00 \\
\hline Just in time & 31,61 & 16,37 & 34,75 & 44,31 & 23,35 & 32,34 & 36,14 & 18,07 & 26,51 & 35,21 & 18,31 & 26,76 & 30,00 & 20,00 & 30,00 \\
\hline Tools of the Certification of suppliers & 23,08 & 23,65 & 39,84 & 26,66 & 27,32 & 46,02 & 23,08 & 23,65 & 39,84 & 21,88 & 23,75 & 40,63 & 20,00 & 20,00 & 40,00 \\
\hline $\begin{array}{l}\text { Regulations consistent with the protection of } \\
\text { the environment }\end{array}$ & 56,09 & 16,56 & 11,68 & 66,51 & 19,64 & 13,85 & 56,09 & 16,56 & 11,68 & 56,52 & 17,15 & 8,70 & 50,00 & 25,00 & 0,00 \\
\hline Environmental Management System & 18,32 & 39,18 & 23,83 & 22,52 & 48,18 & 29,30 & 18,32 & 39,18 & 23,83 & 18,52 & 39,53 & 22,22 & 14,29 & 14,29 & 57,14 \\
\hline Environmental methods for supplier selection & 43,60 & 27,63 & 22,91 & 46,31 & 29,35 & 24,34 & 43,60 & 27,63 & 22,91 & 44,44 & 27,55 & 22,22 & 50,00 & 25,00 & 25,00 \\
\hline $\begin{array}{l}\text { Environmental method of selection of business } \\
\text { partners }\end{array}$ & 16,59 & 22,51 & 34,28 & 22,61 & 30,68 & 46,72 & 16,59 & 22,51 & 34,28 & 16,67 & 23,35 & 33,33 & 25,00 & 25,00 & 25,00 \\
\hline Planning with partners & 35,39 & 20,70 & 28,56 & 41,81 & 24,45 & 33,74 & 35,39 & 20,70 & 28,56 & 35,29 & 20,57 & 29,41 & 33,33 & 16,67 & 33,33 \\
\hline Informatiosn sharing & 43,94 & 2,36 & 34,11 & 54,64 & 2,93 & 42,43 & 43,94 & 2,36 & 34,11 & 42,42 & 2,39 & 33,33 & 40,00 & 0,00 & 40,00 \\
\hline Process orientation & 33,48 & 19,94 & 25,02 & 42,68 & 25,43 & 31,89 & 33,48 & 19,94 & 25,02 & 34,21 & 19,81 & 23,68 & 40,00 & 20,00 & 20,00 \\
\hline SMART & 28,53 & 30,64 & 34,25 & 42,46 & 17,37 & 40,17 & 28,53 & 30,64 & 34,25 & 29,41 & 30,82 & 35,29 & 33,33 & 33,33 & 33,33 \\
\hline Model ROF & 32,74 & 3,01 & 41,75 & 42,24 & 3,89 & 53,87 & 32,74 & 3,01 & 41,75 & 32,50 & 3,15 & 42,50 & 40,00 & 0,00 & 40,00 \\
\hline Models of diffusion of innovation & 46,87 & 2,84 & 19,38 & 67,84 & 4,11 & 28,05 & 46,87 & 2,84 & 19,38 & 45,45 & 2,86 & 18,18 & 33,33 & 0,00 & 33,33 \\
\hline The ability of models of organizational learning & 27,62 & 28,32 & 38,83 & 29,14 & 29,89 & 40,98 & 27,62 & 28,32 & 38,83 & 27,59 & 28,78 & 37,93 & 33,33 & 33,33 & 33,33 \\
\hline Model SERVQUAL & 48,40 & 7,61 & 29,69 & 56,48 & 8,87 & 34,65 & 48,40 & 7,61 & 29,69 & 48,65 & 7,77 & 29,73 & 50,00 & 0,00 & 25,00 \\
\hline Process quality model (PQM) & 21,00 & 25,10 & 26,02 & 29,12 & 34,80 & 36,08 & 21,00 & 25,10 & 26,02 & 21,43 & 25,87 & 25,00 & 25,00 & 25,00 & 25,00 \\
\hline Methods for pollution prevention & 43,18 & 6,98 & 39,84 & 47,98 & 7,76 & 44,27 & 43,18 & 6,98 & 39,84 & 42,86 & 6,83 & 39,29 & 33,33 & 0,00 & 66,67 \\
\hline KPI & 36,40 & 26,81 & 24,55 & 41,48 & 30,55 & 27,97 & 36,40 & 26,81 & 24,55 & 38,24 & 27,36 & 23,53 & 20,00 & 20,00 & 40,00 \\
\hline green procurment & 43,90 & 8,13 & 26,60 & 55,83 & 10,34 & 33,83 & 43,90 & 8,13 & 26,60 & 45,24 & 8,27 & 26,19 & 60,00 & 0,00 & 20,00 \\
\hline Eco labeling & 42,46 & 3,06 & 31,26 & 55,30 & 3,98 & 40,72 & 42,46 & 3,06 & 31,26 & 42,86 & 3,03 & 30,95 & 50,00 & 0,00 & 25,00 \\
\hline LCC & 12,09 & 23,33 & 44,09 & 15,20 & 29,34 & 55,45 & 12,09 & 23,33 & 44,09 & 10,00 & 24,32 & 46,67 & 0,00 & 25,00 & 50,00 \\
\hline
\end{tabular}


Table 2 Analysis of the methods, tools and concepts - empirical verifications - general and manufacturing (Con't)

\begin{tabular}{|c|c|c|c|c|c|c|c|c|c|c|c|c|c|c|c|}
\hline EU directive & 44,37 & 11,74 & 42,14 & 45,16 & 11,95 & 42,89 & 44,37 & 11,74 & 42,14 & 43,90 & 11,57 & 41,46 & 33,33 & 16,67 & 50,00 \\
\hline EU ordinance & 25,08 & 16,43 & 41,56 & 30,19 & 19,78 & 50,03 & 25,08 & 16,43 & 41,56 & 25,81 & 16,91 & 41,94 & 20,00 & 20,00 & 40,00 \\
\hline Sustainable development tools & 41,16 & 28,33 & 16,89 & 47,65 & 32,80 & 19,55 & 41,16 & 28,33 & 16,89 & 42,86 & 28,44 & 14,29 & 50,00 & 25,00 & 0,00 \\
\hline green supplier selections & 21,98 & 23,30 & 33,57 & 27,88 & 29,55 & 42,57 & 21,98 & 23,30 & 33,57 & 20,93 & 23,48 & 34,88 & 20,00 & 20,00 & 40,00 \\
\hline $\begin{array}{c}\text { Partnership with suppliers for sustainable } \\
\text { development }\end{array}$ & 30,69 & 17,37 & 48,96 & 31,63 & 17,90 & 50,46 & 30,69 & 17,37 & 48,96 & 30,95 & 17,21 & 50,00 & 25,00 & 25,00 & 50,00 \\
\hline matrix EPRA & 28,68 & 16,53 & 34,56 & 35,95 & 20,72 & 43,33 & 28,68 & 16,53 & 34,56 & 28,26 & 16,76 & 34,78 & 33,33 & 16,67 & 33,33 \\
\hline Eco-QFD & 29,16 & 23,17 & 32,26 & 34,48 & 27,39 & 38,13 & 29,16 & 23,17 & 32,26 & 29,03 & 23,72 & 32,26 & 20,00 & 20,00 & 40,00 \\
\hline Analysis of material flow (MFA) & 17,99 & 21,59 & 45,56 & 21,13 & 25,36 & 53,51 & 17,99 & 21,59 & 45,56 & 17,78 & 21,71 & 44,44 & 20,00 & 20,00 & 40,00 \\
\hline Total consumption of materials (TMC) & 50,97 & 7,22 & 31,64 & 56,74 & 8,04 & 35,22 & 50,97 & 7,22 & 31,64 & 51,52 & 7,47 & 33,33 & 50,00 & 0,00 & 50,00 \\
\hline ESCOR & 66,50 & 9,28 & 15,75 & 72,65 & 10,14 & 17,21 & 66,50 & 9,28 & 15,75 & 65,63 & 8,98 & 15,63 & 75,00 & 0,00 & 25,00 \\
\hline Value stream mapping - VSM & 34,30 & 18,41 & 34,94 & 39,13 & 21,01 & 39,86 & 34,30 & 18,41 & 34,94 & 35,14 & 18,10 & 35,14 & 40,00 & 20,00 & 20,00 \\
\hline Social life cycle assessment (SLCA) & 26,30 & 12,54 & 48,27 & 30,19 & 14,39 & 55,41 & 26,30 & 12,54 & 48,27 & 26,32 & 12,58 & 47,37 & 33,33 & 16,67 & 33,33 \\
\hline $\begin{array}{c}\text { Indicatos of the chattiness of products and } \\
\text { services (MIPS) }\end{array}$ & 34,00 & 55,38 & 10,25 & 34,12 & 55,59 & 10,29 & 34,00 & 55,38 & 10,25 & 33,33 & 55,77 & 11,11 & 50,00 & 50,00 & 0,00 \\
\hline Ecological baggage & 37,22 & 17,85 & 34,22 & 41,68 & 20,00 & 38,32 & 37,22 & 17,85 & 34,22 & 34,78 & 18,53 & 34,78 & 33,33 & 33,33 & 33,33 \\
\hline Ecoauditing & 42,38 & 2,76 & 40,89 & 49,26 & 3,21 & 47,53 & 42,38 & 2,76 & 40,89 & 41,94 & 2,71 & 41,94 & 40,00 & 0,00 & 40,00 \\
\hline ecological balance & 19,58 & 7,93 & 56,33 & 23,35 & 9,46 & 67,19 & 19,58 & 7,93 & 56,33 & 18,75 & 7,96 & 56,25 & 25,00 & 0,00 & 50,00 \\
\hline inventory of sources of pollution & 40,59 & 15,75 & 23,35 & 50,93 & 19,76 & 29,30 & 40,59 & 15,75 & 23,35 & 40,00 & 15,75 & 24,44 & 40,00 & 20,00 & 20,00 \\
\hline $\begin{array}{c}\text { Good practice in the implementation of green } \\
\text { supply chain management }\end{array}$ & 40,77 & 12,77 & 24,21 & 52,44 & 16,42 & 31,14 & 40,77 & 12,77 & 24,21 & 40,43 & 12,95 & 23,40 & 40,00 & 20,00 & 20,00 \\
\hline Assessment process in terms of environmental & 62,82 & 2,29 & 10,79 & 82,77 & 3,02 & 14,22 & 62,82 & 2,29 & 10,79 & 66,67 & 2,37 & 11,11 & 66,67 & 0,00 & 0,00 \\
\hline $\begin{array}{l}\text { Periodic verification and evaluation of the } \\
\text { results of environmental programs }\end{array}$ & 43,11 & 11,95 & 41,12 & 44,82 & 12,43 & 42,75 & 43,11 & 11,95 & 41,12 & 42,50 & 11,77 & 40,00 & 40,00 & 20,00 & 40,00 \\
\hline Eco-vehicles & 53,60 & 8,06 & 32,12 & 57,16 & 8,59 & 34,25 & 53,60 & 8,06 & 32,12 & 54,05 & 7,87 & 32,43 & 50,00 & 0,00 & 50,00 \\
\hline $\begin{array}{l}\text { Control of emissions occurring in } \\
\text { manufacturing processes }\end{array}$ & 22,26 & 45,23 & 30,33 & 22,76 & 46,24 & 31,01 & 22,26 & 45,23 & 30,33 & 23,81 & 48,75 & 28,57 & 0,00 & 50,00 & 50,00 \\
\hline $\begin{array}{c}\text { Control of emissions occurring in logistics } \\
\text { processes }\end{array}$ & 41,86 & 1,25 & 36,67 & 52,47 & 1,57 & 45,97 & 41,86 & 1,25 & 36,67 & 41,46 & 1,26 & 36,59 & 50,00 & 0,00 & 33,33 \\
\hline Implementation of the Ecoinnovation & 39,14 & 8,49 & 28,76 & 51,24 & 11,11 & 37,65 & 39,14 & 8,49 & 28,76 & 38,71 & 8,29 & 29,03 & 50,00 & 0,00 & 25,00 \\
\hline Eco investment & 22,94 & 29,13 & 24,78 & 29,85 & 37,90 & 32,25 & 22,94 & 29,13 & 24,78 & 22,58 & 29,70 & 25,81 & 25,00 & 25,00 & 25,00 \\
\hline Eco-patents & 33,31 & 14,18 & 32,45 & 41,67 & 17,74 & 40,59 & 33,31 & 14,18 & 32,45 & 33,33 & 14,01 & 33,33 & 33,33 & 16,67 & 33,33 \\
\hline Supplier selection (only with green certificates) & 41,68 & 12,86 & 42,69 & 42,87 & 13,23 & 43,90 & 41,68 & 12,86 & 42,69 & 42,50 & 13,33 & 42,50 & 37,50 & 12,50 & 50,00 \\
\hline
\end{tabular}



Operations and Supply Chain Management 11(2) pp. 82 - 97 @ 2018

Table 2 Analysis of the methods, tools and concepts - empirical verifications - general and manufacturing (Con't)

\begin{tabular}{|c|c|c|c|c|c|c|c|c|c|c|c|c|c|c|c|}
\hline Having a mission of environmental protection & 59,79 & 23,23 & 5,02 & 67,91 & 26,39 & 5,70 & 59,79 & 23,23 & 5,02 & 61,54 & 23,67 & 3,85 & 66,67 & 33,33 & 0,00 \\
\hline The environmental reports & 43,21 & 6,12 & 23,30 & 59,49 & 8,43 & 32,08 & 43,21 & 6,12 & 23,30 & 43,75 & 6,07 & 21,88 & 50,00 & 0,00 & 25,00 \\
\hline Green taxes & 28,58 & 22,46 & 29,39 & 35,53 & 27,93 & 36,54 & 28,58 & 22,46 & 29,39 & 28,57 & 21,94 & 28,57 & 20,00 & 20,00 & 40,00 \\
\hline demand of the organic products & 41,11 & 10,65 & 34,26 & 47,79 & 12,39 & 39,83 & 41,11 & 10,65 & 34,26 & 41,46 & 10,75 & 34,15 & 33,33 & 16,67 & 33,33 \\
\hline Benchmarking & 26,48 & 0,93 & 51,42 & 33,59 & 1,17 & 65,23 & 26,48 & 0,93 & 51,42 & 27,27 & 0,91 & 50,00 & 25,00 & 0,00 & 50,00 \\
\hline TBM (time based Management) & 43,44 & 13,95 & 20,82 & 55,55 & 17,83 & 26,62 & 43,44 & 13,95 & 20,82 & 44,44 & 14,49 & 19,44 & 40,00 & 20,00 & 20,00 \\
\hline BPM (business process Management) & 36,62 & 11,24 & 36,08 & 43,63 & 13,39 & 42,98 & 36,62 & 11,24 & 36,08 & 36,11 & 11,12 & 36,11 & 33,33 & 16,67 & 33,33 \\
\hline LM (lean Management) & 54,12 & 19,04 & 10,65 & 64,57 & 22,72 & 12,71 & 54,12 & 19,04 & 10,65 & 54,55 & 19,59 & 12,12 & 50,00 & 25,00 & 0,00 \\
\hline AM (agile Management) & 33,36 & 31,21 & 27,34 & 36,30 & 33,95 & 29,75 & 33,36 & 31,21 & 27,34 & 33,33 & 29,58 & 27,27 & 50,00 & 25,00 & 25,00 \\
\hline Quick response (QR) & 34,13 & 19,50 & 25,64 & 43,05 & 24,61 & 32,34 & 34,13 & 19,50 & 25,64 & 34,04 & 19,14 & 25,53 & 33,33 & 16,67 & 33,33 \\
\hline ECR & 29,61 & 26,65 & 36,89 & 31,78 & 28,62 & 39,60 & 29,61 & 26,65 & 36,89 & 29,03 & 27,65 & 35,48 & 25,00 & 25,00 & 50,00 \\
\hline Outsourcing & 20,84 & 8,32 & 47,10 & 27,33 & 10,91 & 61,76 & 20,84 & 8,32 & 47,10 & 21,05 & 8,51 & 47,37 & 40,00 & 0,00 & 40,00 \\
\hline SWOT & 33,88 & 14,73 & 29,73 & 43,24 & 18,81 & 37,95 & 33,88 & 14,73 & 29,73 & 32,35 & 15,12 & 29,41 & 40,00 & 20,00 & 20,00 \\
\hline
\end{tabular}


Tundys: Use of Quantitative and Qualitative Methods for Modelling Green Supply Chains

Operations and Supply Chain Management 11(2) pp. 82 - 97 @ 2018

Table 3 Analysis of the methods, tools and concepts - empirical verifications - sales network

\begin{tabular}{|c|c|c|c|c|c|c|c|c|c|}
\hline \multirow{3}{*}{$\begin{array}{l}\text { Methods, instruments and } \\
\text { concepts }\end{array}$} & \multicolumn{9}{|c|}{ Sales network } \\
\hline & \multicolumn{3}{|c|}{ of home appliances } & \multicolumn{3}{|c|}{$\begin{array}{l}\text { of grocery and general } \\
\text { merchandise retailer }\end{array}$} & \multicolumn{3}{|c|}{ of retail-clothing } \\
\hline & $\begin{array}{l}\text { No/not } \\
\text { use }\end{array}$ & $\begin{array}{c}\text { no } \\
\text { opinion }\end{array}$ & $\begin{array}{l}\text { Yes/alwa } \\
\text { ys use }\end{array}$ & $\begin{array}{l}\text { No/not } \\
\text { use }\end{array}$ & $\begin{array}{c}\text { no } \\
\text { opinion }\end{array}$ & $\begin{array}{l}\text { Yes/alwa } \\
\text { ys use }\end{array}$ & $\begin{array}{l}\text { No/not } \\
\text { use }\end{array}$ & $\begin{array}{c}\text { no } \\
\text { opinion }\end{array}$ & $\begin{array}{l}\text { Yes/alwa } \\
\text { ys use }\end{array}$ \\
\hline $\begin{array}{c}\text { Value and supply chain model } \\
\text { M.E. Porter }\end{array}$ & 40,00 & 20,00 & 40,00 & 27,27 & 18,18 & 18,18 & 25,00 & 25,00 & 50,00 \\
\hline Seuring and Goldbach matrix & 0,00 & 100,00 & 0,00 & 66,67 & 50,00 & 50,00 & 0,00 & 100,00 & 0,00 \\
\hline quality filter mapping & 0,00 & 0,00 & 50,00 & 16,67 & 0,00 & 0,00 & 0,00 & 0,00 & 50,00 \\
\hline supply chain response matrix & 20,00 & 20,00 & 40,00 & 30,00 & 10,00 & 10,00 & 25,00 & 0,00 & 50,00 \\
\hline physical structure mapping & 40,00 & 0,00 & 40,00 & 22,22 & 11,11 & 11,11 & 50,00 & 0,00 & 50,00 \\
\hline decision poion analysis & 50,00 & 0,00 & 50,00 & 30,00 & 0,00 & 0,00 & 66,67 & 0,00 & 33,33 \\
\hline Method Eraned Value & 50,00 & 25,00 & 25,00 & 50,00 & 30,00 & 30,00 & 50,00 & 25,00 & 25,00 \\
\hline Model SCOR & 50,00 & 0,00 & 0,00 & 50,00 & 16,67 & 16,67 & 50,00 & 0,00 & 0,00 \\
\hline Model GSCF & 0,00 & 0,00 & 66,67 & 0,00 & 0,00 & 0,00 & 0,00 & 0,00 & 100,00 \\
\hline Model APQC & 40,00 & 20,00 & 20,00 & 33,33 & 16,67 & 16,67 & 40,00 & 20,00 & 20,00 \\
\hline Process mapping & 20,00 & 20,00 & 40,00 & 23,08 & 23,08 & 23,08 & 0,00 & 25,00 & 50,00 \\
\hline Balanced score card & 50,00 & 0,00 & 50,00 & 20,00 & 0,00 & 0,00 & 0,00 & 0,00 & 100,00 \\
\hline production variety funnel & 0,00 & 0,00 & 50,00 & 16,67 & 16,67 & 16,67 & 0,00 & 0,00 & 50,00 \\
\hline demand amplification mapping & 25,00 & 25,00 & 25,00 & 36,36 & 27,27 & 27,27 & 33,33 & 33,33 & 33,33 \\
\hline CPM & 50,00 & 0,00 & 50,00 & 37,50 & 0,00 & 0,00 & 50,00 & 0,00 & 50,00 \\
\hline PERT & 25,00 & 25,00 & 50,00 & 28,57 & 21,43 & 21,43 & 25,00 & 25,00 & 50,00 \\
\hline CCPM & 33,33 & 33,33 & 0,00 & 50,00 & 30,00 & 30,00 & 33,33 & 33,33 & 0,00 \\
\hline SixSigma & 30,00 & 20,00 & 30,00 & 32,00 & 12,00 & 12,00 & 33,33 & 11,11 & 33,33 \\
\hline $\begin{array}{l}\text { cause and effect diagram } \\
\text { (Ishikawa) }\end{array}$ & 14,29 & 14,29 & 42,86 & 23,53 & 11,76 & 11,76 & 14,29 & 14,29 & 42,86 \\
\hline TQM & 33,33 & 16,67 & 33,33 & 26,67 & 20,00 & 20,00 & 33,33 & 16,67 & 33,33 \\
\hline value stream analysis & 50,00 & 0,00 & 50,00 & 20,00 & 20,00 & 20,00 & 0,00 & 0,00 & 100,00 \\
\hline ERP & 0,00 & 50,00 & 50,00 & 42,86 & 28,57 & 28,57 & 0,00 & 50,00 & 50,00 \\
\hline SCM & 0,00 & 0,00 & 50,00 & 25,00 & 12,50 & 12,50 & 0,00 & 0,00 & 50,00 \\
\hline process activity mapping & 50,00 & 50,00 & 0,00 & 57,14 & 28,57 & 28,57 & 50,00 & 50,00 & 0,00 \\
\hline matrix diagram & 20,00 & 20,00 & 40,00 & 41,67 & 25,00 & 25,00 & 20,00 & 20,00 & 40,00 \\
\hline $\begin{array}{l}\text { Organization and standardisation } \\
\text { of the workplace }\end{array}$ & 0,00 & 25,00 & 50,00 & 22,22 & 22,22 & 22,22 & 0,00 & 25,00 & 50,00 \\
\hline Ecoaudit & 20,00 & 20,00 & 40,00 & 37,50 & 12,50 & 12,50 & 25,00 & 0,00 & 50,00 \\
\hline accreditation and certification EU & 0,00 & 50,00 & 50,00 & 40,00 & 40,00 & 40,00 & 0,00 & 50,00 & 50,00 \\
\hline ISO certificates (ISO1400x) & 40,00 & 20,00 & 20,00 & 30,77 & 15,38 & 15,38 & 40,00 & 20,00 & 20,00 \\
\hline ISO 14031 & 0,00 & 0,00 & 50,00 & 0,00 & 0,00 & 0,00 & 0,00 & 0,00 & 50,00 \\
\hline ISO 14001 & 0,00 & 25,00 & 50,00 & 12,50 & 12,50 & 12,50 & 0,00 & 0,00 & 50,00 \\
\hline $\begin{array}{c}\text { Meters and indicators of eco- } \\
\text { efficiency }\end{array}$ & 40,00 & 20,00 & 20,00 & 36,36 & 18,18 & 18,18 & 40,00 & 20,00 & 20,00 \\
\hline LCA & 50,00 & 16,67 & 33,33 & 26,32 & 10,53 & 10,53 & 50,00 & 16,67 & 33,33 \\
\hline Evaluation of the carbon footprint & 0,00 & 25,00 & 50,00 & 20,00 & 20,00 & 20,00 & 0,00 & 25,00 & 50,00 \\
\hline Evaluation of the water footprint & 20,00 & 20,00 & 40,00 & 30,00 & 20,00 & 20,00 & 20,00 & 20,00 & 40,00 \\
\hline TQEM & 50,00 & 0,00 & 0,00 & 42,86 & 0,00 & 0,00 & 50,00 & 0,00 & 0,00 \\
\hline Just in time & 20,00 & 0,00 & 40,00 & 40,00 & 20,00 & 20,00 & 33,33 & 16,67 & 16,67 \\
\hline
\end{tabular}


Tundys: Use of Quantitative and Qualitative Methods for Modelling Green Supply Chains

Table 3 Analysis of the methods, tools and concepts - empirical verifications - sales network (Con't)

\begin{tabular}{|c|c|c|c|c|c|c|c|c|c|}
\hline $\begin{array}{l}\text { Tools of the Certification of } \\
\text { suppliers }\end{array}$ & 25,00 & 25,00 & 50,00 & 30,00 & 20,00 & 20,00 & 25,00 & 25,00 & 50,00 \\
\hline $\begin{array}{l}\text { Regulations consistent with the } \\
\text { protection of the environment }\end{array}$ & 100,00 & 0,00 & 0,00 & 33,33 & 16,67 & 16,67 & 100,00 & 0,00 & 0,00 \\
\hline $\begin{array}{c}\text { Environmental Management } \\
\text { System }\end{array}$ & 33,33 & 33,33 & 0,00 & 42,86 & 42,86 & 42,86 & 0,00 & 50,00 & 0,00 \\
\hline $\begin{array}{l}\text { Environmental methods for } \\
\text { supplier selection }\end{array}$ & 50,00 & 25,00 & 25,00 & 50,00 & 25,00 & 25,00 & 50,00 & 25,00 & 25,00 \\
\hline $\begin{array}{c}\text { Environmental method of } \\
\text { selection of business partners }\end{array}$ & 25,00 & 25,00 & 25,00 & 36,36 & 18,18 & 18,18 & 25,00 & 25,00 & 25,00 \\
\hline Planning with partners & 33,33 & 16,67 & 33,33 & 38,46 & 23,08 & 23,08 & 33,33 & 16,67 & 33,33 \\
\hline Informatiosn sharing & 40,00 & 0,00 & 40,00 & 22,22 & 0,00 & 0,00 & 40,00 & 0,00 & 40,00 \\
\hline Process orientation & 40,00 & 20,00 & 20,00 & 40,00 & 20,00 & 20,00 & 40,00 & 20,00 & 20,00 \\
\hline SMART & 33,33 & 33,33 & 33,33 & 30,00 & 30,00 & 30,00 & 33,33 & 33,33 & 33,33 \\
\hline Model ROF & 40,00 & 0,00 & 40,00 & 16,67 & 0,00 & 0,00 & 40,00 & 0,00 & 40,00 \\
\hline Models of diffusion of innovation & 50,00 & 0,00 & 0,00 & 40,00 & 0,00 & 0,00 & 50,00 & 0,00 & 0,00 \\
\hline $\begin{array}{l}\text { The ability of models of } \\
\text { organizational learning }\end{array}$ & 33,33 & 33,33 & 33,33 & 37,50 & 25,00 & 25,00 & 33,33 & 33,33 & 33,33 \\
\hline Model SERVQUAL & 50,00 & 0,00 & 25,00 & 36,36 & 9,09 & 9,09 & 50,00 & 0,00 & 25,00 \\
\hline Process quality model (PQM) & 33,33 & 33,33 & 0,00 & 42,86 & 28,57 & 28,57 & 33,33 & 33,33 & 0,00 \\
\hline Methods for pollution prevention & 50,00 & 0,00 & 50,00 & 22,22 & 11,11 & 11,11 & 50,00 & 0,00 & 50,00 \\
\hline KPI & 50,00 & 50,00 & 0,00 & 40,00 & 30,00 & 30,00 & 50,00 & 50,00 & 0,00 \\
\hline Green procurement & 50,00 & 0,00 & 25,00 & 33,33 & 8,33 & 8,33 & 50,00 & 0,00 & 25,00 \\
\hline Eco labeling & 50,00 & 0,00 & 25,00 & 16,67 & 0,00 & 0,00 & 50,00 & 0,00 & 25,00 \\
\hline LCC & 0,00 & 25,00 & 50,00 & 22,22 & 22,22 & 22,22 & 0,00 & 25,00 & 50,00 \\
\hline EU directive & 40,00 & 20,00 & 40,00 & 27,27 & 9,09 & 9,09 & 50,00 & 0,00 & 50,00 \\
\hline EU ordinance & 0,00 & 33,33 & 33,33 & 22,22 & 11,11 & 11,11 & 0,00 & 33,33 & 33,33 \\
\hline Sustainable development tools & 33,33 & 33,33 & 0,00 & 60,00 & 30,00 & 30,00 & 50,00 & 50,00 & 0,00 \\
\hline green supplier selections & 20,00 & 20,00 & 40,00 & 38,46 & 23,08 & 23,08 & 20,00 & 20,00 & 40,00 \\
\hline $\begin{array}{l}\text { Partnership with suppliers for } \\
\text { sustainable development }\end{array}$ & 25,00 & 25,00 & 50,00 & 41,67 & 16,67 & 16,67 & 25,00 & 25,00 & 50,00 \\
\hline matrix EPRA & 33,33 & 16,67 & 33,33 & 30,77 & 15,38 & 15,38 & 33,33 & 16,67 & 33,33 \\
\hline Eco-QFD & 25,00 & 25,00 & 25,00 & 44,44 & 22,22 & 22,22 & 33,33 & 33,33 & 33,33 \\
\hline Analysis of material flow (MFA) & 20,00 & 20,00 & 40,00 & 28,57 & 21,43 & 21,43 & 20,00 & 20,00 & 40,00 \\
\hline $\begin{array}{l}\text { Total consumption of materials } \\
\text { (TMC) }\end{array}$ & 66,67 & 0,00 & 33,33 & 40,00 & 10,00 & 10,00 & 66,67 & 0,00 & 33,33 \\
\hline ESCOR & 100,00 & 0,00 & 0,00 & 44,44 & 11,11 & 11,11 & 100,00 & 0,00 & 0,00 \\
\hline Value stream mapping - VSM & 50,00 & 25,00 & 25,00 & 36,36 & 18,18 & 18,18 & 50,00 & 25,00 & 25,00 \\
\hline $\begin{array}{l}\text { Social life cycle assessment } \\
\text { (SLCA) }\end{array}$ & 33,33 & 16,67 & 33,33 & 22,22 & 11,11 & 11,11 & 33,33 & 0,00 & 66,67 \\
\hline $\begin{array}{l}\text { Indicatos of the chattiness of } \\
\text { products and services (MIPS) }\end{array}$ & 50,00 & 50,00 & 0,00 & 60,00 & 60,00 & 60,00 & 50,00 & 50,00 & 0,00 \\
\hline Ecological baggage & 50,00 & 0,00 & 50,00 & 42,86 & 14,29 & 14,29 & 50,00 & 0,00 & 50,00 \\
\hline Ecoauditing & 50,00 & 0,00 & 50,00 & 12,50 & 0,00 & 0,00 & 33,33 & 0,00 & 66,67 \\
\hline ecological balance & 0,00 & 0,00 & 66,67 & 22,22 & 11,11 & 11,11 & 0,00 & 0,00 & 66,67 \\
\hline inventory of sources of pollution & 40,00 & 20,00 & 20,00 & 33,33 & 16,67 & 16,67 & 40,00 & 20,00 & 20,00 \\
\hline $\begin{array}{l}\text { Good practice in the } \\
\text { implementation of green supply } \\
\text { chain management }\end{array}$ & 40,00 & 20,00 & 20,00 & 28,57 & 14,29 & 14,29 & 40,00 & 20,00 & 20,00 \\
\hline
\end{tabular}


Tundys: Use of Quantitative and Qualitative Methods for Modelling Green Supply Chains

Operations and Supply Chain Management 11(2) pp. 82 - 97 @ 2018

Table 3 Analysis of the methods, tools and concepts - empirical verifications - sales network (Con't)

\begin{tabular}{|c|c|c|c|c|c|c|c|c|c|}
\hline $\begin{array}{c}\text { Assessment process in terms of } \\
\text { environmental }\end{array}$ & 100,00 & 0,00 & 0,00 & 50,00 & 0,00 & 0,00 & 100,00 & 0,00 & 0,00 \\
\hline $\begin{array}{l}\text { Periodic verification and } \\
\text { evaluation of the results of } \\
\text { environmental programs }\end{array}$ & 40,00 & 20,00 & 40,00 & 40,00 & 10,00 & 10,00 & 50,00 & 0,00 & 50,00 \\
\hline Eco-vehicles & 50,00 & 0,00 & 50,00 & 36,36 & 9,09 & 9,09 & 50,00 & 0,00 & 50,00 \\
\hline $\begin{array}{l}\text { Control of emissions occurring in } \\
\text { manufacturing processes }\end{array}$ & 0,00 & 50,00 & 50,00 & 66,67 & 50,00 & 50,00 & 0,00 & 50,00 & 50,00 \\
\hline $\begin{array}{l}\text { Control of emissions occurring in } \\
\text { logistics processes }\end{array}$ & 40,00 & 0,00 & 40,00 & 27,27 & 0,00 & 0,00 & 40,00 & 0,00 & 40,00 \\
\hline $\begin{array}{c}\text { Implementation of the } \\
\text { Ecoinnovation }\end{array}$ & 33,33 & 0,00 & 33,33 & 37,50 & 12,50 & 12,50 & 33,33 & 0,00 & 33,33 \\
\hline Eco investment & 0,00 & 33,33 & 33,33 & 44,44 & 33,33 & 33,33 & 0,00 & 50,00 & 0,00 \\
\hline Eco-patents & 20,00 & 20,00 & 40,00 & 45,45 & 18,18 & 18,18 & 25,00 & 25,00 & 25,00 \\
\hline $\begin{array}{l}\text { Supplier selection (only with } \\
\text { green certificates) }\end{array}$ & 40,00 & 20,00 & 40,00 & 36,36 & 9,09 & 9,09 & 40,00 & 20,00 & 40,00 \\
\hline $\begin{array}{c}\text { Having a mission of } \\
\text { environmental protection }\end{array}$ & 66,67 & 33,33 & 0,00 & 50,00 & 25,00 & 25,00 & 66,67 & 33,33 & 0,00 \\
\hline The environmental reports & 50,00 & 0,00 & 0,00 & 44,44 & 11,11 & 11,11 & 50,00 & 0,00 & 0,00 \\
\hline Green taxes & 20,00 & 20,00 & 40,00 & 44,44 & 22,22 & 22,22 & 25,00 & 25,00 & 25,00 \\
\hline demand of the organic products & 50,00 & 0,00 & 25,00 & 25,00 & 8,33 & 8,33 & 50,00 & 0,00 & 25,00 \\
\hline Benchmarking & 0,00 & 0,00 & 66,67 & 16,67 & 0,00 & 0,00 & 0,00 & 0,00 & 100,00 \\
\hline TBM (time based Management) & 40,00 & 20,00 & 20,00 & 33,33 & 11,11 & 11,11 & 40,00 & 20,00 & 20,00 \\
\hline $\begin{array}{c}\text { BPM (business process } \\
\text { Management) }\end{array}$ & 33,33 & 0,00 & 33,33 & 40,00 & 10,00 & 10,00 & 33,33 & 0,00 & 33,33 \\
\hline LM (lean Management) & 50,00 & 25,00 & 0,00 & 40,00 & 20,00 & 20,00 & 50,00 & 25,00 & 0,00 \\
\hline AM (agile Management) & 50,00 & 25,00 & 25,00 & 40,00 & 30,00 & 30,00 & 33,33 & 33,33 & 33,33 \\
\hline Quick response (QR) & 33,33 & 16,67 & 33,33 & 30,77 & 15,38 & 15,38 & 33,33 & 16,67 & 33,33 \\
\hline ECR & 33,33 & 33,33 & 33,33 & 33,33 & 22,22 & 22,22 & 33,33 & 33,33 & 33,33 \\
\hline Outsourcing & 0,00 & 0,00 & 66,67 & 18,18 & 9,09 & 9,09 & 0,00 & 0,00 & 66,67 \\
\hline SWOT & 40,00 & 20,00 & 20,00 & 33,33 & 11,11 & 11,11 & 40,00 & 20,00 & 20,00 \\
\hline
\end{tabular}

Table 4 Ranking of the most popular tools and methods using in polish companies in the evaluation of the functioning of the green supply chain

\begin{tabular}{|c|l|l|l|}
\hline 1. & Model GSCF & 17. & LCC \\
\hline 2. & Balanced score card & 18. & Value and supply chain model M.E. Porter \\
\hline 3. & ecological balance & 19. & Supplier selection (only with green certificates) \\
\hline 4. & Benchmarking & 20. & PERT \\
\hline 5. & quality filter mapping & 21. & EU directive \\
\hline 6. & Partnership with suppliers for sustainable development & 22. & Model ROF \\
\hline 7. & Organization and standardization of the workplace & 23. & EU ordinance \\
\hline 8. & Social life cycle assessment (SLCA) & 24. & $\begin{array}{l}\text { Periodic verification and evaluation of the results of environmental } \\
\text { programs }\end{array}$ \\
\hline 9. & ISO 14031 & 25. & Ecoauditing \\
\hline 10. & Ecoaudit & 26. & physical structure mapping \\
\hline 11. & Outsourcing & 27. & Rating of the water footprint \\
\hline 12. & production variety funnel & 28. & Tools of the Certification of suppliers \\
\hline 13. & value stream analysis & 29. & Methods for pollution prevention \\
\hline 14. & Analysis of material flow (MFA) & 30. & CPM \\
\hline 15. & Process mapping & 31. & The ability of models of organizational learning \\
\hline 16. & Rating of the carbon footprint & 32. & ISO 14001 \\
\hline & & \\
\hline
\end{tabular}




\section{DISCUSSION, VALUE AND LIMITATIONS OF THE STUDY}

In the absence of research (including literature) regarding the use of quantitative methods in Polish conditions, this element of research and this model show a pioneering approach, especially in terms of the study of this economy. The empirical studies conducted by the author are used for presentation of methods and techniques for the assessment, parameterization and verification of the functionality of the chain, allowing the formation of conclusions related to Polish economic reality. To complete the research and building of the models, quantitative methods must be used, based not only on indications of the literature but on showing how operations research supports evaluation of green supply chains.

The value of this work consists in (1) organizing a set of tools (2) identification of the most commonly used methods and using them as the basis for the construction of green supply chains for the sectors in question; (3) proposing a model for assessing green supply chains, (4) identification, on the basis of empirical research, of the elements (in the field of management tools) used to assess supply chains in Poland. The conclusions that arise indicate broad and significant possibilities for the evaluation of green supply chains and the availability of many tools conducive to such solutions. The barrier is knowledge of the tools by those who manage and make decisions for supply chains, as well as their degree of usefulness (not all of them can be adapted to any industry). These tools, methods and instruments can definitely be used to build models, based on mathematics, statistics and operations research, as well as for a higher quality (stochastic) approach and research on the supply chain. The full picture of the evaluation system must certainly use both types of method, and combinations of them. This may indicate that there are some methods that are valid and suitable for all sectors. Models should be dedicated, but there are some basic elements that definitely must be used with this modeling.

In conclusion, and in answer to the questions of the research process, it should be pointed out that an excessive number of methods, tools and concepts can be a barrier in the assessment of a supply chain, because not all tools are useful and known for each chain. It seems that the best option is to select a maximum of about 20 elements, which will serve as a basis for research on the greening of processes and activities. Another solution is choosing a group of tools and evaluation chain based on the scope of the group.

\section{ACKNOWLEDGMENT}

This paper is as part of the project financed by the National Science Centre granted on the basis of the decision DEC-2013/09/B/HS4/02707.

\section{REFERENCES}

Beamon B. (2008), Sustainability and the Future of Supply Chain Management, Operations and Supply Chain Management, an International Journal, Vol. 1 (1), pp. 4-18.

Beamon, B. M. (1998). Supply chain design and analysis:: Models and methods. International journal of production economics, 55(3), pp. 281-294.

Bortz, J., Döring, N. (2002), Forschungsmethoden und Evaluation,
3. Aufl., Berlin u.a. pp. 225.

Brandenburg, M., Govindan, K., Sarkis, J., \& Seuring, S. (2014). Quantitative models for sustainable supply chain management: Developments and directions. European Journal of Operational Research, 233(2), pp. 299-312.

Carter, C. R., \& Dresner, M. (2001). Purchasing's role in environmental management: cross- functional development of grounded theory. Journal of Supply Chain Management, 37(2), pp. 12-27.

Carter, C.R., Carter, J.C. (1998), Interorganizational determinants of environmental purchasing: Initial evidence from the consumer products industries. Decision Science 29 (3), pp. 659-684.

Ciesielski M., (Ed.). (2009), Instrumenty zarządzania łańcuchami dostaw. Polskie Wydawnictwo Ekonomiczne.

Fink A. (1998), Conducting research literature reviews: from paper to the internet. Thousand Oaks: Sage;

Guide Jr, V. D. R., \& Van Wassenhove, L. N. (2009). OR FORUMthe evolution of closed-loop supply chain research. Operations research, 57(1), pp. 10-18.

Hall, J. (2000). Environmental supply chain dynamics. Journal of Cleaner Production, 8 (6), pp. 455-471.

Khoo, H. H., Spedding, T. A., Bainbridge, I., \& Taplin, D. M. (2001), Creating a green supply chain. Greener Management International, pp. 71-88.

Kleindorfer, P. R., Singhal, K., \& Wassenhove, L. N. (2005). Sustainable operations management. Production and operations management, 14(4), pp. 482-492.

Kothari, C. R. (2004). Research methodology: Methods and techniques. New Age International., s. 15.

Lamming, R., \& Hampson, J. (1996). The environment as a supply chain management issue. British journal of Management, 7(s1), pp. 45-S62.

Lee, S.Y. (2008), Drivers for participation of small and mediumsized suppliers in green supply initiatives. Supply chain management, An international journal, 13(3), pp. 185-198

Preuss L., 2001, In dirty chains? Purchasing and greener manufacturing. Journal of Business Ethics, 34(3), pp. 345359

Rao, P., \& Holt, D. (2005). Do green supply chains lead to competitiveness and economic performance? International journal of operations \& production management, 25(9), pp. 898-916.

Rothenberg, S., Pil, F. K., \& Maxwell, J. (2001). Lean, green, and the quest for superior environmental performance. Production and Operations Management, 10(3), pp. 228-243.

Sasikumar, P., \& Kannan, G. (2009). Issues in reverse supply chain, part III: classification and simple analysis. International Journal of Sustainable Engineering, 2(1), pp. 2-27.

Seuring, S. (2012). A review of modeling approaches for sustainable supply chain management. Decision Support Systems. http://dx.doi.org/10.1016/ j.dss.2012.02.053

Seuring, S., \& Gold, S. (2012). Conducting content-analysis based literature reviews in supply chain management. Supply Chain Management: An International Journal, 17(5), pp. 544-555.

Seuring, S., \& Müller, M. (2008a). From a literature review to a conceptual framework for sustainable supply chain management. Journal of cleaner production, 16(15), pp. 1699-1710.

Seuring, S., \& Müller, M. (2008b). Core issues in sustainable supply chain management - A Delphi study. Business Strategy and the Environment, 17(8), pp. 455-466

Sheu, J.B., (2008), Green supply chain management, reverse logistics and nuclear power generation. Transportation Research Part E: L Logistics and Transportation Review, 44(1), pp. 19-46

Sheu, J.B., Chou, Y.H. and Hu, C.C., (2005), An integrated logistics operational model for green supply chain management. Transportation Research Part E: Logistics and 
Transportation Review, 41 (4), pp. 287-313

Simpson, D., Power, D., \& Samson, D. (2007). Greening the automotive supply chain: a relationship perspective. International Journal of Operations \& Production Management, 27(1), pp. 28-48.

Srivastava S. K. (2007), Green supply-chain management: A stateof - the-art - literature review, International Journal of Management Reviews, vol 9(1), pp. 53-80

Sulistio, J., \& Rini, T. A. (2015). A Structural Literature Review on Models and Methods Analysis of Green Supply Chain Management. Procedia Manufacturing, 4, pp. 291-299

Vachon S, Klassen RD. (2006), Extending green practices across the supply chain: the impact of upstream and downstream integration. International Journal of Operations \& Production Management; Vol. 26 Iss: 7, pp.795 - 821

Vachon, S. and Klassen, R.D., 2007. Supply chain management and environmental technologies: the role of integration. International Journal of Production Research, 45 (2), pp. 401-423.

Vachon, S., 2007. Green supply chain practices and the selection of environmental technologies. International Journal of Production Research, 45 (18), pp. 4357-4379.

Walker H., Di Sisto L., McBain D, 2008, Drivers of environmental supply chain practices: lessons from the public and private sec tors, Journal of purchasing and supply chain management, $14(1)$, pp. 69-85

van Hoek, R.I., 1999. From reversed logistics to green supply chains. Supply Chain Management, 4 (3), pp. 129-135.

Wang, F., Lai, X., \& Shi, N. (2011). A multi-objective optimization for green supply chain network design. Decision Support Systems, 51, pp. 262-269.

Welford, R., \& Frost, S. (2006). Corporate social responsibility in Asian supply chains. Corporate Social Responsibility and Environmental Management, 13(3), pp. 166-176.

Witkowski J., (2010). Zarządzanie łańcuchem dostaw: koncepcje, procedury, doświadczenia. Polskie Wydawnictwo Ekonomiczne.

Wu, H. J., \& Dunn, S. C. (1995). Environmentally responsible logistics systems. International journal of physical distribution \& logistics management, 25(2), pp. 20-38.

Yakovleva, N., Sarkis, J., \& Sloan, T. (2012). Sustainable benchmarking of supply chains: the case of the food industry. International Journal of Production Research, 50(5), pp. 1297-1317.

Zhu Q., Sarkis J. (2004) Relationships between operational practices and performance among early adopters of green supply chain management practices in Chinese manufacturing enterprises. Journal of Operations Management 22 (3), pp. 265-289

Zhu, Q. and Sarkis, J. (2006), An inter-sectoral comparison of green supply chain management in China: drivers and practices. Journal of Cleaner Production, 14, pp. 472-486.

Zhu, Q., Sarkis, J. and Lai, L.-H. (2007a), Green supply chain management: pressures, practices and performance within the Chinese automobile industry. Journal of Cleaner Production, 15 (11-12), pp. 1041-1052.

Zhu, Q., Sarkis, J. and Lai, L.-H., (2007b). Initiatives and outcomes of green supply chain management implementation by Chinese manufacturers. Journal of Environmental Management, 85 (1), pp. 179-189.

Zhu, Q., Sarkis, J. and Lai, L.-H. (2008a). Green supply chain management implications for 'closing the loop'. Transportation Research Part E: Logistics \& Transportation Review, 44 (1), pp. 1-18.

Zhu, Q., Sarkis, J. and Lai, L.-H. (2008b), Confirmation of a measurement model for green supply chain management practices implementation. International Journal of Production Economics, 111 (2), pp. 261-273

Blanka Tundys, PhD. is an Assistant Professor at the Department of Logistics, at the Faculty of Management and Economics of Services, University of Szczecin, Poland. Her main research areas are: green supply chain management, green logistics, measurement of green supply chain, processes modeling and city logistics. She is an author and co-author of 80 publications and has written one book (City Logistics - in polish language, 2008 I. ed., 2013 II ed.). She was main contractor in 5 international research projects (finance by German Academic Exchange Services and Deutsch-Polnische Wissenschaftsstiftung). She has gotten three times a scholarship of DAAD (German Academic Exchange Services) foundation (2001, 2004-2005, 2011). In 2004-2005 she has gotten a scholarship at the Fachhochschule Osnabrück (Germany), while she was preparing her doctoral dissertation. She has gotten a three scholarship by LLP - Erasmus-Program. Since 2015 she is a reviewer for the Journal of Business and economics (USA), Editorial Board Member and Committee member of the international conferences. 